\title{
EFEKTIVITAS KERAJINAN TENUN BAGI MASYARAKAT PRESPEKTIF EKONOMI ISLAM (STUDI KASUS DI DESA SUKARARE KEC. JONGGAT KAB. LOMBOK TENGAH)
}

\author{
Sri Husnul Khotimah', H. Bahruddin ${ }^{2}$ \\ ${ }^{1,2}$ Prodi Hukum Ekonomi Syari'ah Fakultas Agama Islam Universitas Hasyim Asy'ari \\ ${ }^{1}$ sri.khusnu199@gmail.com \\ ${ }^{2}$ bahruddinalbari@gmail.com
}

\begin{abstract}
Effectiveness is a measure that unites the extent to which the target time has an effect and brings results aimed at achieving success in an activity. Craft is something that is related to handicrafts or activities related to goods or services produced from traditional handicrafts. Weaving is a technique for making fabrics, originally woven fabrics were made because of a cross between two threads that were intertwined perpendicular to each other. The analysis used by researchers to measure the effectiveness of the management of the weaving craft is the building of an Islamic economy based on five universal values, namely: Tauhid (faith), 'Adl (justice), Nubuwwah (Prophethood), Khilafah (government), and mahad (outcome). This study aims to determine how the effectiveness of weaving crafts for the community based on an Islamic economic perspective. This study uses qualitative methods and a phenomenological approach to data collection techniques carried out by interviews. And the object of research is the people of Sukarare Village. From the results of the study it can be concluded that the effectiveness of weaving crafts in Sukarare Village for the community according to an Islamic economic perspective has been said to be effective because it has fulfilled what is desired, namely to provide employment for rural communities and to meet their daily needs and is in accordance with Islamic economic standards. based on five universal values, namely: tawhid (faith), 'adl (justice), Nubuwwah (prophetic), Khilafah (leader), and maad (result)
\end{abstract}

Keywords: Effectiveness, weaving craft, Islamic economics

\begin{abstract}
Abstrak: Efektivitas merupakan ukuran yang menyatukan sejauh mana target waktu yang mempunyai pengaruh dan membawa hasil yang bertujuan mencapai keberhasilan dalam suatu kegiatan Kerajinan adalah suatu hal yang berhubungan dengan karya tangan atau kegiatan yang berhubungan dengan barang atau jasa yang dihasilkan dari kerajinan tangan tradisional. Tenun adalah teknik pembuatan kain, awalnya kain tenun dibuat karena adanya persilangan antara dua benang yang terjalin saling tegak lurus satu sama lain. Analisis yang digunkan oleh peneliti untuk mengukur efektivitas pengelolaan kerajinan tenun adalah bangunan ekonomi Islam yang di dasarkan atas lima nilai universal, yaitu: Tauhid (keimanan), 'Adl (keadilan), Nubuwwah (Kenabian), Kekhilafahan (pemerintah), dan mahad(hasil). Penelitian tersebut bertujuan untuk mengetahui bagaimana efektivitas kerajinan tenun untuk masyarakat berdasarkan perspektif ekonomi Islam, penelitian ini menggunakan metode kualitatif serta pendekatan fenomenologis tehnik pengumpulan data dilakukan dengan wawancara. Dan objek penelitian adalah masyarakat Desa Sukarare. Dari hasil penelitian dapat disimpulan bahwa efektivitas kerajinan tenun di Desa Sukarare bagi masyarakat menurut perspektif ekonomi Islam sudah di katakana efektif karena sudah memenuhi apa yang diinginkan yaitu memberikan lapangan pekerjaan untuk masyarakat desa dan untuk memenui kebutuhan sehari-hari serta sudah sesuai dengan standar ekonomi islam yang di dasarkan atas lima nilai universal yaitu: tauhid (keimanan), 'adl (keadilan), Nubuwwah (ke nabian), Khilafah (pemimpin), dan maad (hasil)

Kata kunci:Efektifitas, kerajinan tenun,ekonomi islam
\end{abstract}




\section{Pendahuluan}

Bangsa Indonesia merupakan bangsa yang terkenal akan budaya, bahasa, dan beragam suku. Salah satu aneka ragam budaya yang dimiliki Indonesia adalah warisan budaya yang patut dibanggakan yaitu beragam-ragam kain dan tenun tradisional. Indonesia juga terdapat pulau yang sangat kental akan adat budaya dan kekhasannya dengan hasilhasil lokalnya yang menarik dan unik, yakni di pulau Lombok. Di pulau Lombok terdapat berbagai macam lapangan pekerjaan yang dapat meningkatkan per ekonomian masyarakat, menanam padi, tembakau, menanam kacang-kacangan dimusim panas. Tetapi ada satu lapangan pekerjaan yang bukan hanya untuk meningkatkan perekonomian saja tapi menjadi keunikan bagi pulau lombok tersendiri. Yakni kerajinan tenun yang berada di Desa Sukarare.

Sebagian budaya kreatif yang dimiliki perempuan suku Sasak Lombok khususnya Desa Sukarare adalah menenun. Pada dahulu kala, sejak umur 10 tahun semua orang tua wajib mengajarkan anaknya menenun karena filosofi ini telah mentradisi bagi penganut suku Sasak Lombok khususnya Desa Sukarare. Desa Sukarare bisa di katakan sebagai peninggalan kebudayaan lama Sasak berusaha mempertahankan diri sejak dahulu sampai sekarang. Zaman sekarang, Sukarare terkenal sebagai daerah di Lombok bahkan kerajinan tersebut telah berkembang pesat menjadi home industri setelah banyakanya dikunjungi oleh wisatawan dari luar daerah bahkan luar negeri. Desa Sukarare juga salah satu Desa tradisional yang ada di Lombok yang di jadikan tempat wisata lokal dengan hasil tenunan yang bagus dan sudah di kenal oleh masyarakat luas.
Adapun hasil kerajinan yang terkenal di desa Sukarare yaitu kain songket tenun. Dimana pekerjaan tersebut dijadikan pencaharian pokok masyarakat Sukarare untuk memenuhi kebutuhan sehari-hari, dan untuk meningkatkan perekonomian. Melalui kerajinan tenun yang di kelola selama ini oleh masyarakat Lombok khususnya diDesa sukarare, kerajinan tenun tersebut bukan hanya untuk meningkatkan perekonomiannya saja.akan tetapi sudah menjadi salah satu bagian dari kekayaan warisan terdahulu.

Di Desa Sukarare terdapat satu kelompok kerajinan tenun yang bisa di katakana masyarakat nya menjadikan kerajinan tenun tersebut sebagai wadah atau tempat untuk me ningkatkan perekonoiannya, kar yawannya dari masyarakat-masyarakat menengah ke bawah tetapi masyrakat disana sudah menjadikan kerajinan tenun tersebut sebagai wadah untuk mencari atau untuk memenuhi kebutuhan mereka.

Kerajinan kain tenun di Desa Sukarare sudah merekrut banyak tenaga kerja, sehingga sekarang bisa mengurangi tingkat pengangguran serta dapat memberikan keuntungan bagi masyarakat setempat khususunya para pekerja atau karyawannya.

Permasalahan tersebut di rumuskan dalam pertanyaan: 'Bagaimana sistem pengelolan kerajinan tenun di Desa Sukarare kec Jonggat kab Lombok Tengah?

\section{Metode}

Dalam Proses karya Ilmiah penulis menggunakan pendekatan diskripsi analisis tentang kerajinan tenun di Desa Sukarare, pada penelitian ini penulis menggunakan kepustakaan dan penelitian dengan uji di lapangan. Metode penelitian yang digunakan adalah metode penelitian kualitatif. 
Metode penelitian kualitatif adalah metode yang dilakukan langsung oleh peneliti melalui pengumpulan data dengan mengajukan pertanyaan, melihat secara langsung, mendengar informasi dari informan masyarakat desa Sukarare. Penelitian ini di lakukan di Desa Sukarare kecamatan Jonggat Kabupaten Lombok Tengah. Dalam pembuatan artikal penulis menggunakan pendekatan kualitatif yang berproses penelitian yang menghaslkan data diskriptif berupa data yang berbentuk tulisan,lisan atau dari orang yang di amati

Data penelitian yang digunakan terdiri dari data primer dan sekunder. Data primer adalah data yang paling utama dalam penelitian. Data sekunder adalah informasi yang diperoleh secara tidak langsung. Tapi dari pihak ketiga setelah data terkumpul peneliti selanjutnya menganalisa data-data tersebut dengan cara mengklarifikasi data tersebut sehingga bisa menjawab masalah yang diteliti. Penelitian ini menggunaan dua metode yaitu deduktif dan deskriptif.

\section{Hasil dan Pembahasan}

Desa Sukarare adalah satu dari 10 desa di wilayah kecamatan Jonggat, Provinsi Nusa Tengaara barat. Desa Sukarare bagi kaum perempuan sektor pertanian dijadikan suatu pekerjaannya bahkan mereka pun juga melakukan pekerjaan sebagai pengrajin tenun tradisional godongan.

Godongan adalah satu perangkat tenun tradisional yang sederhana dan manual tetapi menghasilkan karya tenun yang berkualitas dengan motif yang beragam dan memiliki daya saing. Produk-produk yang dimaksud antara lain:

Songket, Kain panjang, Selimut, Selendang, Udengakan tetapi banyak nama kain yang lagi buming pada saat ini, yaitu Kembang Komaq, Regi Genep, Kain Selingkuh, Keker, dan lain sebaginaya. Dalam hal ini menenun sudah menjadi kebiasaan perempuan desa Sukarare, dengan menenun mereka bisa memenuhi kebutuhan sehari-hari dan bisa mengembangkan bakat yang dimiliki oleh kaum wanita yang ada di sukarara, selain bisa menenun mereka juga meneruskan peninggalan nenek moyang terdahulu.

Produk tenun Desa Sukarare telah dikenal di seluruh Nusantara maupun mancanegara dan sangat meminati untuk semua kalangan, hal ini bisa diperhatikan dari kunjungan wisatawan di Desa Sukarare. Dengan kondisi tersebut Desa Sukarare ditetapkan sebagai salah satu" Desa penyangka pariwisata Mandalika" yang sekarang sedang dikembangkan, dibenahi, serta dibangun oleh Negara sebagai kawasan ekonomi khusus. Oleh karena itu desa Sukarare berupaya meningkatkan perannya secara aktif dan atraktif memper kenalkan dan mempromosikan produk andalannya yaitu tenun tradisional sukarare.

Langkah-langkah promosi yang di lakukan adalah memperkenalkan tenunnannya sebagai berikut:

a. Seminar gelar budaya

b. Pameran

c. Bazar. Baik tingkat regional maupun nasional

d. Di bawah koordinasi pemerintah

Tujuan adanya kerajinan tenun yang ada di Desa Sukarare adalah untuk meningkatkan perekonomian masyarakat setempat dan sebelum adanya kerajinan tenun tersebut masyarakat Desa Sukarare kesulitan dalam mencari pekerjaan sehingga banyak yang menjadi pengangguran, setelah adanya kerajinan tenun tersebut angka pengangguran yang ada di desa Sukarara bisa berkurang, dan bagi lakilaki yang ada di desa Sukarara sebagai 
penyalur atau memasarkan kelokasi wisata yang ada di Lombok dan memasarkan melalui online selain dari memesarkan ketempat wisata dan online masyarakat setempat juga bisa memasarkan sendiri.

Sebelum menenun masyarakat Desa Sukarare biasanya mereka mulai dari menyiapkan bahan baku yaitu kapas. Pada umumnya warga akan memetik atau mengambili bahan baku tersebut di ladangnya sendiri yang berada di sekitaran rumah. Tetapi aktivitas kebiasaan ini menjadi jarang dilakukan dan masyarakat Desa Sukarare langsung membeli kapan di pasar- pasar di sekitaran Desa Sukarare, jika memetik sendiri maka akan membutuhkan waktu yang begitu lama, terlebih dahulu kapan akan dijemur sampai kering dan juga membutuhkan waktu berhari- hari untuk menjemurnya,setelah kering kapas tersebut akan di pintal oleh alat pintalan yang masih sederhana atau tradisional terbuat dari kayu supaya bisa menjadi bahan baku benang, selama proses pemintalan membutuhkan waktu yang tidak sebentar disebabkan ada hal yang harus dilakukan terlebih dahulu yaitu merapikan kapas sebelum dilakukan pemintalan sehingga menghasilkan benang untuk bahan dasar penenun.

Selanjutnya kapas tersebut akan dibentuk menjadi pintalan benang warna putih lalu digulung melalui alat sederhana yaitu kayu. Alat pemintalan yang wujudnya seperti tiang berdiri lurus kemudian diberi dua kayu yang meluntang mewujudkan empaat sisi. Selanjutnya setelah berbentuk menjadi benang lalu benang tersebut Tanek (menghani) artinya suatu proses dalam pembentukan ragam hias, serta mengukur lebar dan panjang kaen sesuai keinginan. Dengan cara memintil atau memilitkan benang pada alat menghani sesuai kebutuhan atau pesanan, selanjutnya Ngensik Suri (nyujuk) artinya penyususnan benang biasa dan benang gun bandulnya proses memasukkan benang biasa yang setelah di tanek kedalam sisir alat tenun dengan cara memasukkan setiap helai benang di masukkan ke celah-celah serat sisir dengan alat penyuntik atau sesuai yang telah di tentukan.selanjutnya

Gulung(menggulung) artinya benang yang sudah di tanek, nginsik suri atau sudah melalui tahapan- tahapan sebelumnya kemudian di gulung, setelah di gulung baru dilakukan penenun untuk menghasilkan sebuah kain tenun tradisional yang membutuhkan waktu yang lumayan lama sekitar dua minggu untuk pembuatan kain yang membutuhkan motif seperti kain songket, akan tetapi jika bentuk kain yang di tenun itu kain yang biasa seperti kain polosan tidak memakai motif maka waktunya tidak begitu lama seperti menenun kaen songket yang bermotif, akan memakan waktu sekitaran 4 sampai 5 hari untuk penyelesaian satu kain di Sukarare.

Ekonomi Islam sebagai pengumpulan prinsip-prinsip umum tentang ekonomi yang diambil dari Alqur'an dan As-sunah dengan pembangunan pondasi sebagai dasar pokok nash mempertimbangan waktu dan kondisi. Beberapa ahli ekonomi Islam memaknai ekonomi Islam sebagai suatu pendalaman ilmu tentang perilaku Islam dalam usaha sebagai pemenuhan alat kebutuhan yang memiliki batas di dalam kerangka syariah Islam. Makna lain ekonomi Islam sebagai ilmu tentang perilaku orang muslim yang dibingkai dalam syariah Islam. Jadi ilmu ekonomi Islam sebagai bidang ilmu sosial yang tentu saja tidak bebas dari nilai moral. Nilai-nilai moral sebagai aspek normatif yang menjadi masukan dalam menganalisis fenomena 
ekonomi dan pengambilan keputusan yang di bangkai syari'ah.

Seperti yang dijelaskan di dalam Al- qur'an surah saba': 24. Yaitu.

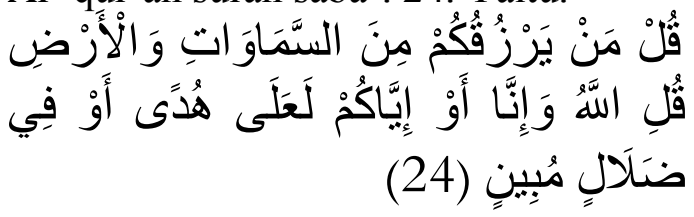

Katakanlah (Muhammad). siapakah yang memberi rizki kepadamu dari langit dan bumi 'katakanlah, 'Allah, "dan sesungguhnya kami atau kamu (orang-orang musyrik), pasti berada dalam kebenaran atau dalam kesesatan yang nyata.

Melakukan aktifitas ekonomi merupakan pekerjaan yang harus dilakukan oleh manusia, akan tetapi melaksanakan aktifitas ekonomi baik yang hubungannya dengan alam (sumber daya alam) atau manusia (mua'malah). Oleh sebab itu analisis yang digunakan oleh peneliti untuk mengukur efektivitas sistem pengelolaan kerajinan tenun di Desa Sukarare adalah bangunan ekonomi Islami yang di dasarkan atas lima nilai universal, yaitu: Tauhid (keimanan), Adl (keadilan), Nubuwwah (kenabian), khilafah ( pemerintah), dan ma'ad (hasil).

\section{Tauhid (keesaan Tuhan)}

Tauhid merupakan suatu dasar utama dalam ajaran Islam. Dengan tauhid, manusia dapat menyaksikan bahwa tidak ada satupun yang layak disembah selain Allah, dan tidak ada pemilik langit, bumi dan seisinya dan seluruh atau sekaligus pemiliknya, termasuk pemilik manusia dan seluruh sumber daya yang ada. Sedangkan manusia diamanahi untuk memiliki, mengelola dan untuk memanfaatkan untuk sementara. Oleh karena itu kelompok kerajinan tenun di Desa Sukarare sudah menjalankan bangunan ekonomi Islam tentang tauhid karena masyarakat tersebut sudah bisa menjalankan amanah dari Allah untuk mengelola dan memanfaatkan kemampuan yang di berikan olehNya, karena setiap apa yang diberikan oleh Allah terhadap hambanya akan diminta pertanggung jawabkan termasuk aktivitas ekonomi.

Allah berfirman dalam surat Alisra' ayat 36 :

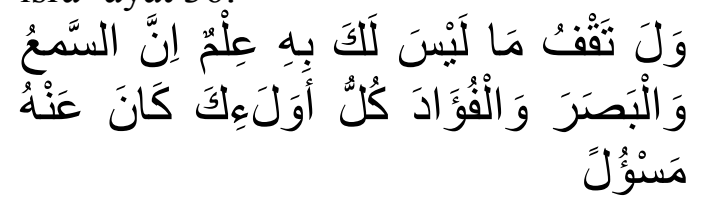

"Dan janganlah kamu mengikuti apa yang kamu tidak mempunyai pengetahuan tentang-Nya. Sesung guhNya pendengaran, peng lihatan dan hati, semuanya itu akan diminta pertanggung jawabnya.' (QS. Al- Isra: 36).

\section{Adl (keadilan)}

Kata adil dalam Islam dimaknai dengan tidak menzilimi dan tidak didzalimi. keterlibatan ekonomi dari nilai ini adalaj sebagai pelaku ekonomi tidak diperbolehkan yang bertujuan mendapatkan keuntungan pribadi jika hal tersebut pihak lain bisa rugi dan bisa merusak alam. Dengan adanya kerajinan tenun yang ada di Desa Sukarare tidak dikatakan untuk mengejar keuntungan perekonomian saja, tetapi bertujuan untuk menciptakan lapangan pe kerjaan bagi masyarakat yang tidak mempunyai pekerjaan atau pe ngangguran. Karena Islam mendidik umatnya manusia untuk dapat bertanggung jawab kepada keluarganya, fakir miskin, Negara dan keseluruhan makhluk yang berada di bumi ini.

\section{Nubuwwah (kenabian)}

Setiap muslim harus bisa meneladani sifat Nabi Muhammad SAW untuk diterapkan bisa diaplikasikan ke dalam kehidupan sehai-hari, membelajarkan bagaimana 
hidup yang baik dan benar di dunia, dan membelajarkan agar bisa kembali (taubat) keasal-muasalnya, segala rasul adalah model terbaik yang harus diteladani manusia agar mendapat keselamatan didunia dan diakhirat. Pada umumnya sifat-sifat Nabi harus diteladani oleh manusia dalam melakukan bisnis ekonomi yaitu: siddik (benar atau jujur), amanah (tanggung jawab), fathanah (kecerdikan kebisaksanaan entelek tualitas), tablig (komunikasi, ke terbukaan, pemasaran). Oleh karena itu baik yang aktif bekerja sebagai karyawan penenun maupun sebagai pengepul agar bias meneladani dan mencotohkan keempat sifat rasul tersebut supaya pekerjaan mencapai target tepat dan baik sesuai keinginan.

\section{Khilafah (pemerintah)}

Dalam Islam pemerintahan me mainkan peranan kecil akan tetapi sangat pentig dalam perekonomian peran yang paling utama adalah memastikan bahwa perekonomian suatu Negara berjalan dengan lancar sesuai syari'at Islam.

Allah berfirman dalam Al-Qur'an bahwa manusia diciptakan untuk menjadi Khalifah dibumi, artinya untuk menjadi pemimpin dan pemakmur bumi.

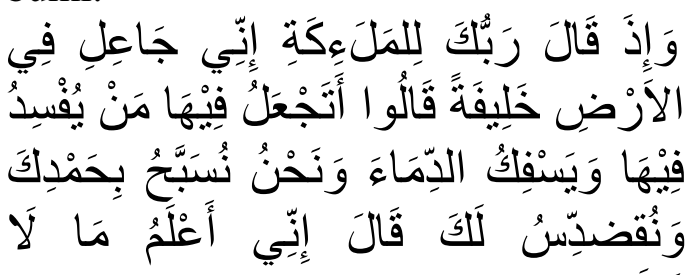

تَنَاُكَُونَ)

"Ingatlah ketika Tuhanmu berfikir kepada para malaikat: sesungguhnya aku hendak menjadikan seseorang khlafah dimuka bumi" mereka berkata:"mengapa engkau hendak menjadikan khilafah dibumi itu orang yang akan membuat kerusakan padanya dan menumpuhkan darah, padahal kami senantiasa bertasbih dengan memuji
Engkau dan mensucikan Engkau?" Tuhan berfirman:"sesungguhnya Aku me ngetahi apa ynag tidak kamu ketahui." (QS. Al-baqarah :30)

Dari ayat diatas dapat dijelaskan bahwa manusia diciptakan oleh Allah untuk menjadikan kholifah dimuka bumi ini, selain menjadi kholifah atau wakil Allah manusia juga bertugas sebagai pemakmur bumi dan alam semesta.Oleh karena itu dengan adanya kerajinan tenun yang ada di Desa Sukarare bisa mewujudkan maslahah yang maksimum selain itu kerajinan tenun tersebut juga bisa memberikan lapangan pekerjaan bagi masyarakat dan bisa meneruskan meninggalan nenek myang terdahulu.

\section{Ma'ah (hasil)}

Imam Ghazali mengemukakan bahwa motifasi para pelaku ekonomi adalah untuk memperoleh keuntungan/laba/profit baik laba materil aupun non materil secara harfiah $m a$ 'ad artinya kembali karena kita semua akan kembali kepada Allah. Allah berfirman bahwa manusia diciptakan di muka bumi ini sebagai pejuang, hasil perjuangan tersebut akan mendapatkan ganjaran, baik didunia maupun diakhirat barang siapa yang berbuat baik maka akan dibalas dengan kebaikan dan barang siapa yang berbuat jahat akan dibalas dengan setimpal sesuai dengan perbuatan tersebut. Oleh sebab itu, ma'ad dapat didefinisikan sebagai imbalan atau ganjaran. Nilai implikasinya adalah pada kehidupan ekonomi bisnis. Imam Ghazali menyatakan bahwa motifasi para pelaku usaha adalah bisnis adalah untuk mendapatkan sebuah laba, baik laba didunia maupun diakhirat. Masuknya kerajinan tenun di Lombok tengah Khususnya di Desa Sukarare dimana masyarakat bisa berjuang dalam bekerja dan bisa mengasah bakat sebagai 
penenun, dimana dengan melaksanakan pekerjaan maka mereka akan mendapatkan hasil atas perjuangan mereka. Hasil tersebut akan diperoleh oleh orang-orang yang mau bekerja keras untuk mendapatkan hasil

Berdasarkan efektivitas sistem ekonomi pengelolaan kerajinan tenun yang di jalankan saat ini sudah bisa dikatakan efektif karena sudah memenuhi bangunan ekonomi Islami yang dasarnya adalah Tauhid ( keimanan), ádl (keadilan), Nubuwwah (kenabian), Khilafah (pemerintah), dan ma'ad (hasil).

Berdasarkan perspektif ekonomi Islam mengenai efektivitas sistem pe ngelolaan kerajinan dalam me ningkatkan perekonomian dan konsumsi masyarakat sudah bisa dikatakan mencapai tujuan utama dari sistem ekonomi Islam, tetapi pendapatan ekonomi masyarakat di Desa Sukarare saat ini belum bisa dikatakan terpenuhi karena pen dapatan masyarakat sebelum maupun sesudh adanya kerajinan tenun itu sama saja berdasarkan hasil penelitian dari masyarakat Desa Sukarare. Sistem ekonomi Islam bertujuan untuk: mencapai falah, pendistribusian secara merata dan adil, kebutuhan tersedia, dan penegakan keadilan sosial.

\section{Simpulan}

Berdasarkan hasil penelitian penulis di atas, dapat di simpulkan bahwa Efektivitas kerajinan tenun di Desa Sukarare bagi masyarakat menurut perspektif ekonomi Islam sudah di katakana efektif karena sudah memenuhi apa yang diinginkan yaitu adanya kegiatan kerajinan tenun untuk memberikan lapangan pekerjaan untuk masyarakat desa dan untuk memenui kebutuhan sehari-hari untuk meneruskan peninggalan orang-orang terdahulu,mengolah bahan mentah menjadi bahan baku yaitu dari kapas yang di ambil dari pepohonan setelah itu diproses menjadi benang, lalu disiapkan waktu menenun dan menyiapkan bahan dan alat untuk menenun. Pengelolaan tersebut sudah sesuai dengan bangunan ekonomi islam yang di dasarkan atas lima nilai universal yaitu: tauhid (keimanan), 'adl (keadilan), Nubuwwah (ke nabian), Khilafah (pemimpin), dan maad (hasil).

\section{Daftar Pustaka}

Al-Qur'an terjemahan

Cahudhry, Sharif. Muhammad, (2012). system ekonomi Islam, Prenada Media Group. Jakarta.

Depertemen pendidikan dan Kebudayaan, (2012). Kamus Besar Bahasa Indonesia, Jakarta: Balai Pustaka.

Huda Choirul. (2015), Ekonomi Islam, Semarang: CV Karya Abadi Jaya.

Huda dkk Nurul. (2009) Ekonomi Makro Islam, PT. Kencana, Jakarta.

Huda Nurul. 2009, Economi Macro Islam,

Huda Qamarul. (2011), Fiqh Muamalah, Yogyakarta: Teras. Jakarta: Kencana.

Karim A Adiwarman. (2015), Ekonomi Makro Islami,Jakarta: PT Raja Grafindo Persada.

Karim A Adiwarman. (2015), Ekonomi Mikro Islami, Jakarta: PT RajaGrafendo Persada.

Mardianti, (2016). Kain Tenun Tradisional Dusun Sade, Rembitan,Pujut, Lombok Tengah $N T B$, Fakultas Bahasa dan Seni.

Misanam Munrakhim. (2008), Ekonomi Islam, Jakarta: PT Raja Grafindo Persada.

Muhammad, (2007). Prinsip-Prinsip Ekonomi Islam, PT. Graha Ilmu, Yogyakarta. 
Ismail. Nabawi, (2009). Ekonomi IslamPerspektif Teori, Sistem dan Aspek Hukum, Surabaya: Putra Media Nusantara.

Noor Ghafur Ruslan Abdul. (2013), Konsep distribusi dalam Ekonomi di Indonesia, Pustaka Pelajar, Yogyakarta.

Nurohman Dede. (2011), Memahami Dasar-dasar Ekonomi Islam. Yogyakarta: Teras

Rivai Veithzal,Andi Buchari, (2009), Islamic Ekonomics, Jakarta : PT. Aksara

Rozalinda, (2016). Ekonomi Islam, Jakarta: PT Raja Grafindo Perseda.

Rozalinda, (2016), Ekonomi Islam, Jakarta :PT Grafinda Persada.

Suriani, (2012), Efektivitas Usaha Tenun Songket Melayu Riau dilihat dari perspektif ekonomi Islam, Fakultas Syai'ah dan ilmu hukum. 